\title{
6. LOWER CRETACEOUS SEDIMENTS BENEATH THE MARCUS ISLAND ARCHIPELAGIC APRON: DSDP SITE 198
}

\author{
The Shipboard Scientific Party ${ }^{1}$
}

\section{SITE DATA}

Occupied: 10-14 Oct. 1971

Position: Abyssal basin north of Marcus Island; lat $25^{\circ} 49.5^{\prime} \mathrm{N}$

long $154^{\circ} 35.0^{\prime} \mathrm{E}$

Water Depth: 5848 meters

Number of Cores: 6

Total Penetration: 258 meters

Deepest Unit Recovered: ?Jurassic-Early Cretaceous fossils in center bit between Cores 5 and 6

Main Results: In the deep Pacific basin north of Marcus Island, the base of the acoustic transparent layer is Mesozoic in age. The opaque layer consists of chert and alternating soft sediments of Santonian to Campanian age. Basement was neither reached nor sampled due to a mechanical failure of the rig but is at least as old as Santonian or Campanian and is probably older.

\section{BACKGROUND}

The site was chosen to contribute to the knowledge of the evolution and early history of the deep western Pacific. The nature and age of the basal sediments were, as in the case of previous sites, the main objectives. At this site (Figures 1 and 2), the upper transparent layer is 120 meters thick and presented an excellent situation for spudding in. The opaque layer is rather dark and formidable looking (Figure 3), but beneath it the basement surface is intermittently discernable drawing a faint profile resembling the topography of the modern East Pacific Rise. Although no clear sharply contrasting lower transparent layer is shown in the records, there does seem to be a suggestion of it particularly between the highest peaks of the basement topography.

Nearly three days were lost at Site 197 while the drillers made repeated attempts to blow or twist off the pipe which was stuck in the hole. This, plus having perhaps devoted too much time trying in vain to accomplish the aims of Prospect 20-1 at Sites 194-197, made it necessary to consider what changes in the cruise plan might release additional time for drilling. Prospect $20-2$ at $29 \mathrm{~N}-161 \mathrm{E}$ was

\footnotetext{
${ }^{1}$ Bruce C. Heezen, Lamont-Doherty Geological Observatory; Ian D. MacGregor, University of California, Davis; Helen P. Foreman, Oberlin College; George Forristall, Eidgenössische Technische Hochschule, Zürich; H. Hekel, Queensland Geological Survey, Brisbane; Reinhard Hesse, Technische Hochschule, Munich; Robert H. Hoskins, New Zealand Geological Survey, Lower Hutt; E. John W. Jones, University College, London; Ansis Kaneps, Scripps Institution of Oceanography, La Jolla; Valeri A. Krasheninnikov, Academy of Sciences, Moscow; Hakuyu Okada, Kagoshima University, Japan; Michael H. Ruef, Washington Department of Ecology, Olympia.
}

an extremely attractive area with sufficient upper transparent for spudding in and a clearly defined lower transparent layer and basement as drilling objectives. However, Prospect 20-2 was the long way around a right triangle from Site 197 east to Prospect 20-2 and then south to Prospect 20-3, so it was reluctantly decided to reject Prospect $20-2$ and gain 30 hours drilling time by taking the southeast course along the hypotenuse. ARIES V records indicated that 100 meters of upper transparent sediments could be found along the south side of the deep basin which lies north of the Marcus-Wake seamounts and south of the Shatsky Rise. The underlying stratigraphy was as unknown as any in the western Pacific, and if basement could be dated and the early stratigraphic history determined, valuable knowledge could be gained. Also, the results of early drilling suggested a Lower Cretaceous age for the Shatsky Rise area, and the south side of the basin gave a bit more distance from the scene of our previous frustration and a hope of gaining another point to establish a pattern of crustal ages.

\section{OPERATIONS}

The ship proceeded on a southeast course from Site 197 toward the south side of the basin flanked on the south by the Marcus-Wake seamounts. On the afternoon of 9 October, the reflection records indicated a favorable region, but the drillers had not completed all of the necessary repairs to the rig. Proceeding to the southeast, a series of seamounts were crossed culminating in a sharp fault scarp 600 meters high. The repairs were completed to the rig by 2330 on 9 October. A site was chosen about 8 miles southeast of the fault over a faintly drawn basement high. The ship's course was reversed at 0600 on 10 October and the beacon dropped at 0645 . The depth was 5858 meters. Ship's personnel had judged the weather to be too rough to bring collars and pipe from the hold while under way so about eight hours of station time were required to make up the new bottom hole assembly as new collars and bumper subs had to be brought out of the hold, tested, and put in the new bottom hole assembly. The bottom hole assembly was completed at 1615 on 10 October.

At 0400 on 11 October, the power sub was put in service. On the way down the float valve, which had been propped open with a piece of wood, started to flap so the core barrel was sent down to hold the valve and stop it from flapping. On starting the pumps, pressure built up, indicating a plugged bit, and it was assumed that some material in the pipe had blocked the vents, although it seemed more likely that bottom had been reached and sediment had plugged it. After a few minutes, the pumps cleared the bit and the string was washed down to 53 meters and Core 1 attempted. 


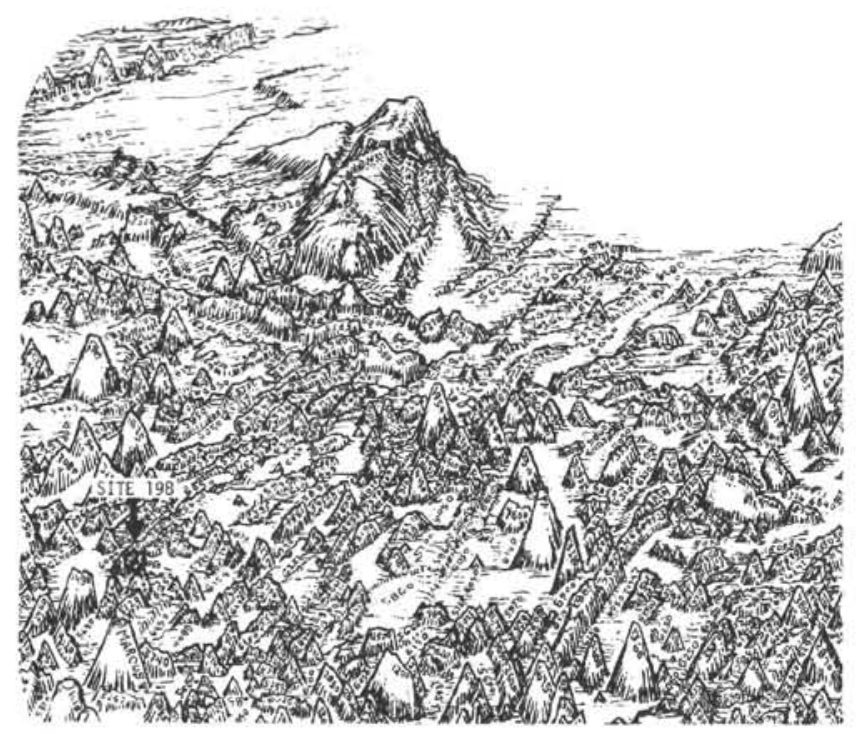

Figure 1. Location of Site 198.

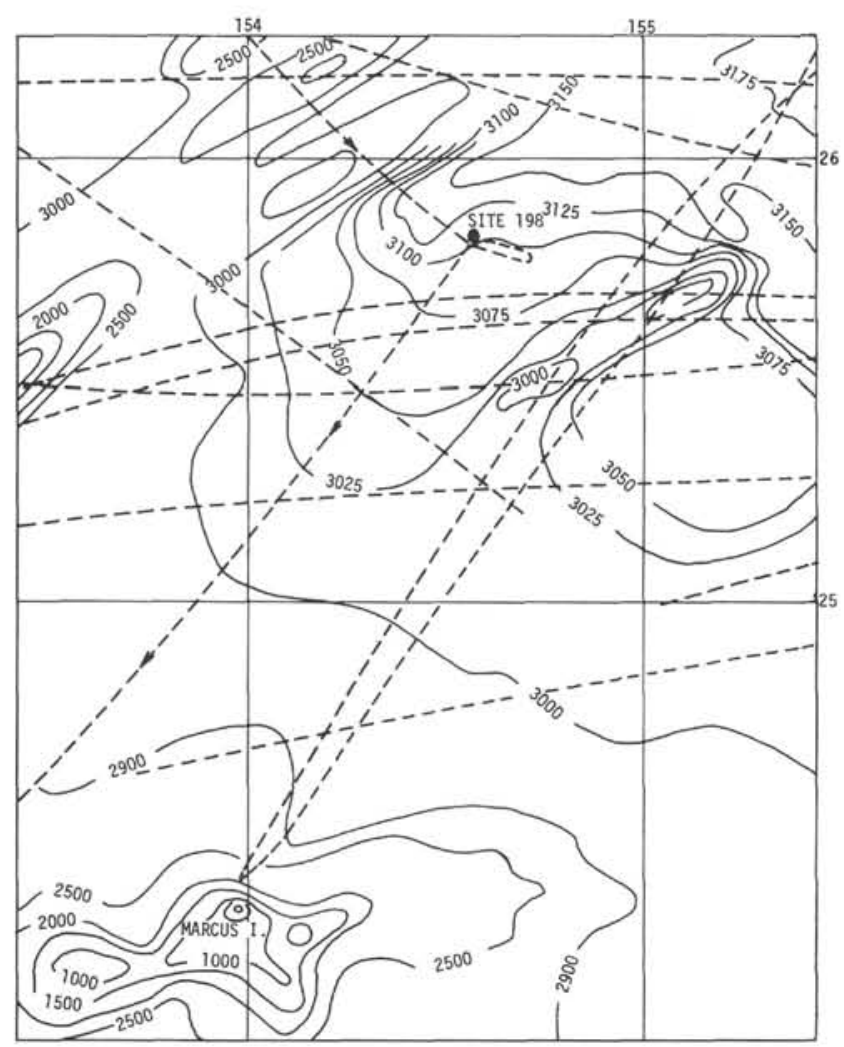

Figure 2. Bathymetry in the vicinity of Site 198 (basea on various sounding lines). Contour interval 100 tau (1 tau $=1 / 400 \mathrm{sec}$ ).

The overshot failed to bring up the barrel on the first attempt. It was sent down again and returned without the core barrel. Then it was found that the string would not rotate. The pipe was brought up 100 meters and rotated, but then the string became lighter by about 25,000 pounds indicating the loss of part or all of the bottom hole assembly. The hole was abandoned at 0900 and the trip up begun. Thus, another 30 hours were lost from the dwindling working time, and it seemed obvious that one more site must be dropped from the schedule.

With the loss of the bottom hole assembly at Hole 198, the supply of collars and bumper subs aboard became critically low. Thus, the bottom hole assembly used on Hole 198A included only three bumper subs in an effort to reserve sufficient tools to make up one more assembly if it were needed. The work of assembling a new bottom hole assembly began at 1900 on 11 October when the top collar from Hole 198 was recovered, with the remainder of the assembly missing.

A new bottom hole assembly was made up in eight hours, but at 0200 on 12 October, it fell through the slips in the rotary table and was lost. A third bottom hole assembly was made up and lowered to the bottom. Hole $198 \mathrm{~A}$ was spudded in at 2130 on 12 October and drilled to 60 meters when at 2230 a power failure in the engine room left the rig without power until 0230 on 13 October. Finally, with power restored, Core 1 was cut (5948.5-5958 meters, see Table 1). The hole was cored continuously (Core 2, 5958-5967.5 meters; Core 3, 5967.5-5977 meters; Core 4, 5977-5983 meters) through the upper transparent on into the top of the opaque layer when recovery (Core 5, 5983-5992.5 meters) decreased to a few chert chips. Because of the fear that stopping to core would bring on the usual deterioration of hole conditions, it was decided to drill on to 250 meters below bottom before coring again. Core 6 (6107-6114 meters) came up empty at 0600 on 14 October. The string seemed to torque-up on bottom but was found to still torque-up when the bit was lifted off the bottom of the hole. At first, it was feared that the hole had collapsed, but then it was decided that it was the power sub that would not rotate. Inspection revealed pieces of metal in the oil of the swivel. The hole was abandoned and the string brought to the surface. The bit showed no excessive wear and it seemed to be in good condition: bearings were still in good shape with seals in place, and the buttons were not much worn. Further inspection confirmed the trouble in the swivel, and messages from shore indicated that it would be best to proceed to Guam to pick up and install new bearings for the swivel. Upon departing Site 198 at 2015 hours 14 October, a course was set for Guam.

\section{NATURE OF THE SEDIMENTS}

There was no recovery from Hole 198 for the reasons previously explained. In Hole 198A, the portion of the upper transparent layer immediately overlying the opaque layer was continuously cored in order to gain information about the nature of the sediments in the transitional zone and about the age of the top of the opaque layer (Table 1). Five cores were obtained from subbottom depths between 90.5 and 134.5 meters (or a total depth between 5948.5 and 5992.5 meters, respectively). A sixth attempt was made between subbottom depths of 251 and 258 meters with no recovery. At that time, failure of the power swivel stopped drilling operations at this site.

In the cored sequence above the opaque layer, a downward transition is observed from very stiff, dark brown, limonitic zeolitic clays and silts with abundant ash components, to less dark radiolarian-rich zeolitic silts with 


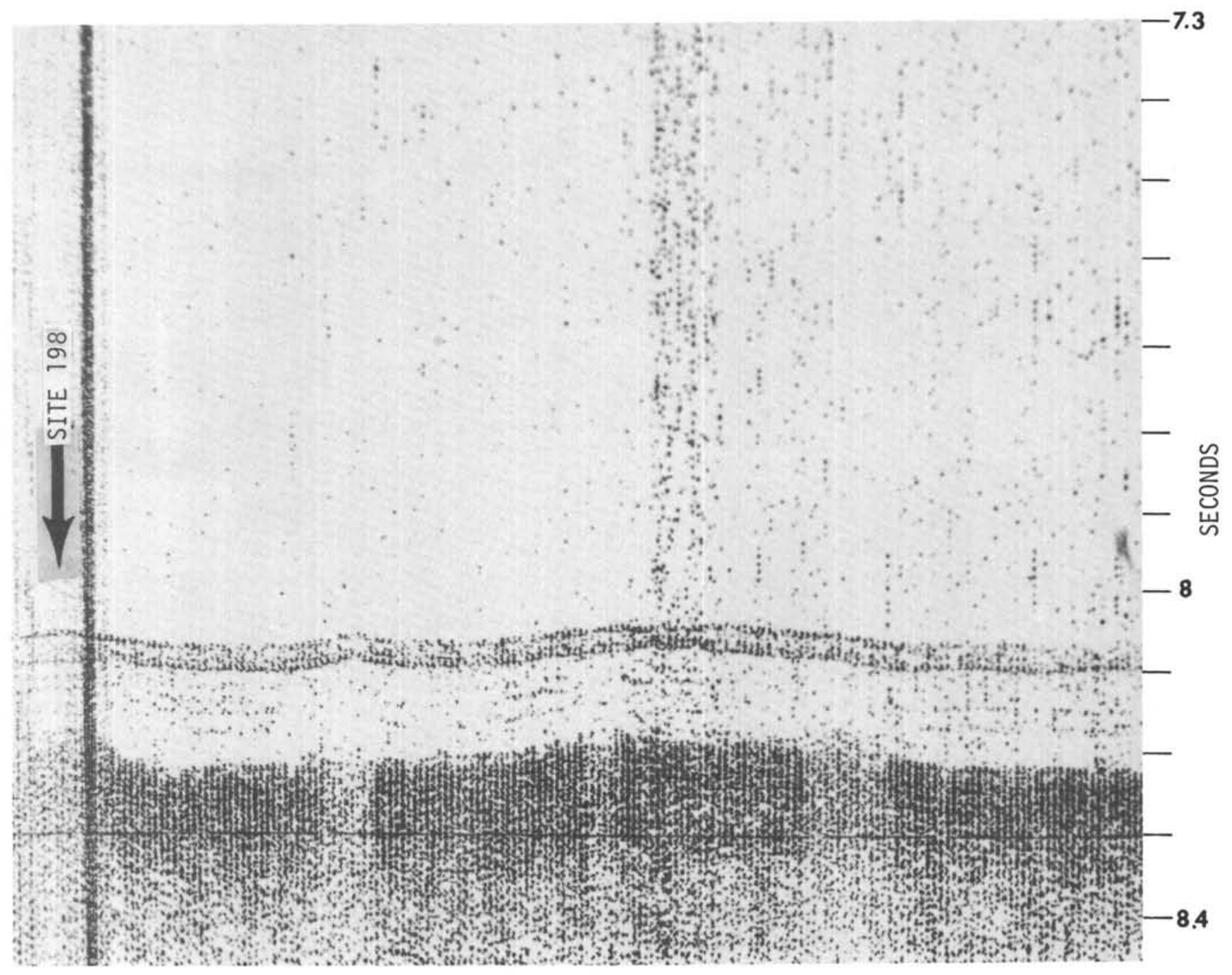

Figure 3. Glomar Challenger seismic profile across Site 198 on site approach.

increasing proportions of light volcanic ash and intercalated chert. The cherts of the opaque layer were brought up in Core 5 (Figure 4).

The age of this suite of sediments is entirely Cretaceous with Campanian radiolarian microfaunas appearing in Cores 4 and 5 immediately above the chert.

Severe disturbance by drilling operations makes the cores almost useless for any further detailed study of the sedimentary structures, particularly the burrowing structures of organisms and the fine laminations in nonburrowed portions. The presence of sedimentary structures can only be inferred from the rarely-found less disturbed portions of the sediment and from chert pieces where they have been preserved.

Correlation of the drilled section to the seismic profile for the site, and the drilling record, are shown in Figure 5.

\section{Core 1A (90.5-100 Meters)}

The sediment is a very stiff, dark brown limonitic zeolitic silty clay which is rich in volcanic glass fragments. Admixture of water during the drilling process produced a less stiff, completely mottled clay in which blebs of the less disturbed, very stiff material float. A yellow pink decomposed pebble of pumice $(2 \times 3 \mathrm{~cm})$ yielded glass fragments showing an abundance of vesicles under the microscope. The dark brown silty clay always contains small amounts of manganese micronodules (less than 5 per cent) and frequently quartz and feldspar (usually also less than 5 percent). Casts of foraminifera were found among the brown components (?limonite).

\section{Core 2A (100-109.5 Meters)}

The two sections, which are Late Cretaceous in age, are made up of homogeneous, very stiff, dark brown limonitic zeolitic clay and silty clay with some pale brown spots at the base of Section 2, less rich in iron oxides and hydroxides. Glass fragments, feldspar, and opaque micronodules are common. Rare (?) limonitized microfossils are present.

\section{Core 3A (109.5-119 Meters)}

This core consists almost entirely of the same very stiff, homogeneous, dark brown, Late Cretaceous limonitic zeolitic clay and silty clay encountered in Core $2 \mathrm{~A}$. Some 
TABLE 1

Coring Summary, Hole 198A

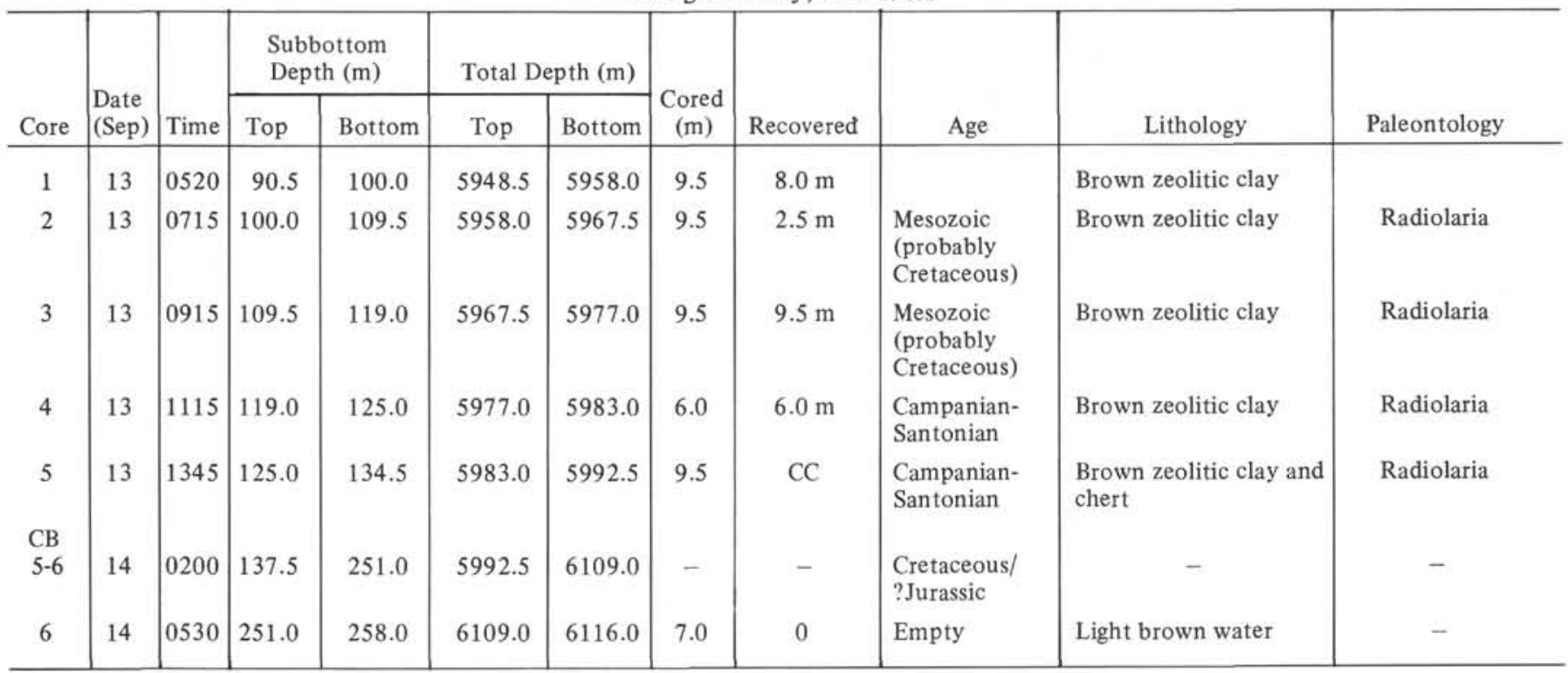

Note: Mud line is at 5858 meters.

yellow to pale brown spots in Section 3 consist of dominant zeolites with considerably less iron oxides and hydroxides than in the dark brown clays. In the deepest part of the core, these zeolitic silts occur as light yellowish brown laminae and bands a few millimeters to a few centimeters wide. Due to drilling disturbances, they form diapir-like structures. Glass fragments are abundant throughout the core.

\section{Core 4A (119-126 Meters)}

The color of the brown zeolitic limonitic clays and silty clays becomes lighter in this core due to a decrease in the content of iron oxides and hydroxides. Simultaneously, the number and thickness of the pale brown and yellowish pinkish bands of the zeolitic, glass shard-rich clays (probably altered ashes) increases downward. In the lower half of the core, abundant Radiolaria appear (beginning in Section 4 at $490 \mathrm{~cm}$ ), changing the character of the dominant sediment type into a yellow brown radiolarianrich zeolitic silt.

Indurated whitish to pale yellow ash layers between 528 and $533 \mathrm{~cm}$ and 565 and $571 \mathrm{~cm}$ display incipient stages of chert formation. Five major patches of light ash occur in Section 5 .

The uppermost pieces of compact, pale pinkish to pale brown and brown chert appear in the lowermost part of the core at 725 and $742 \mathrm{~cm}$. Internal structures in these pieces are somewhat nebulous and seem to reflect mottling by burrowing organisms.

The core is probably early Campanian in age.

HOLE 198

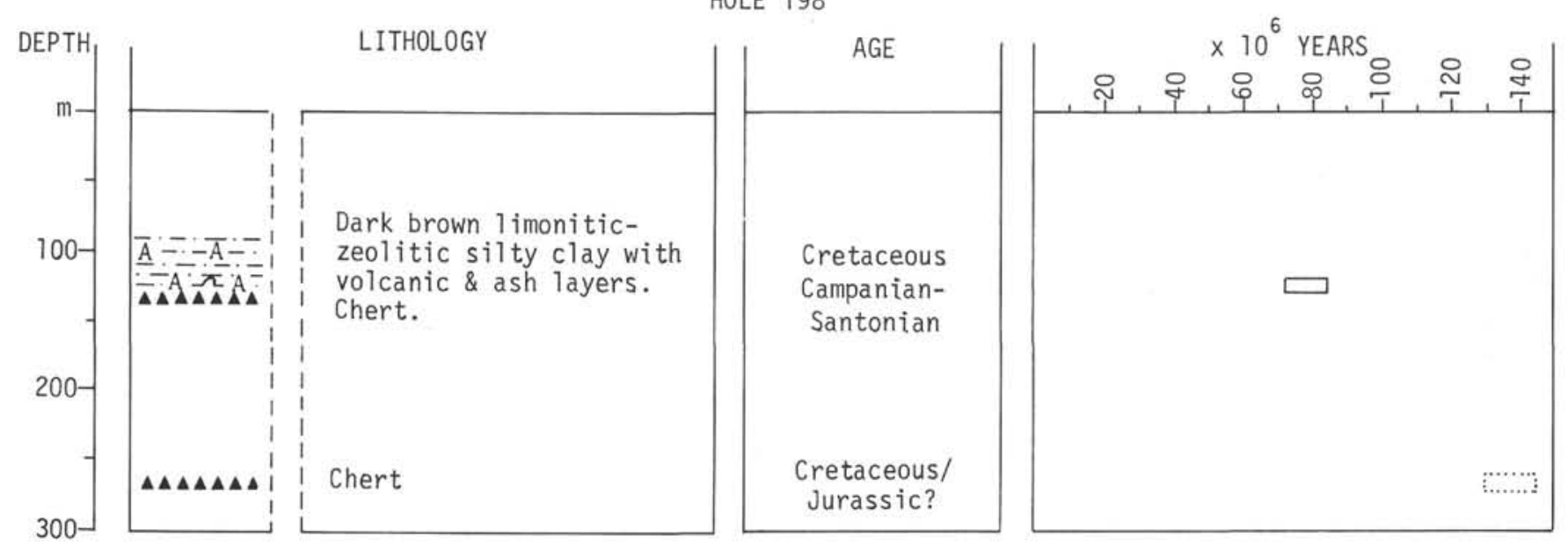

Figure 4. Stratigraphy of Site 198. 


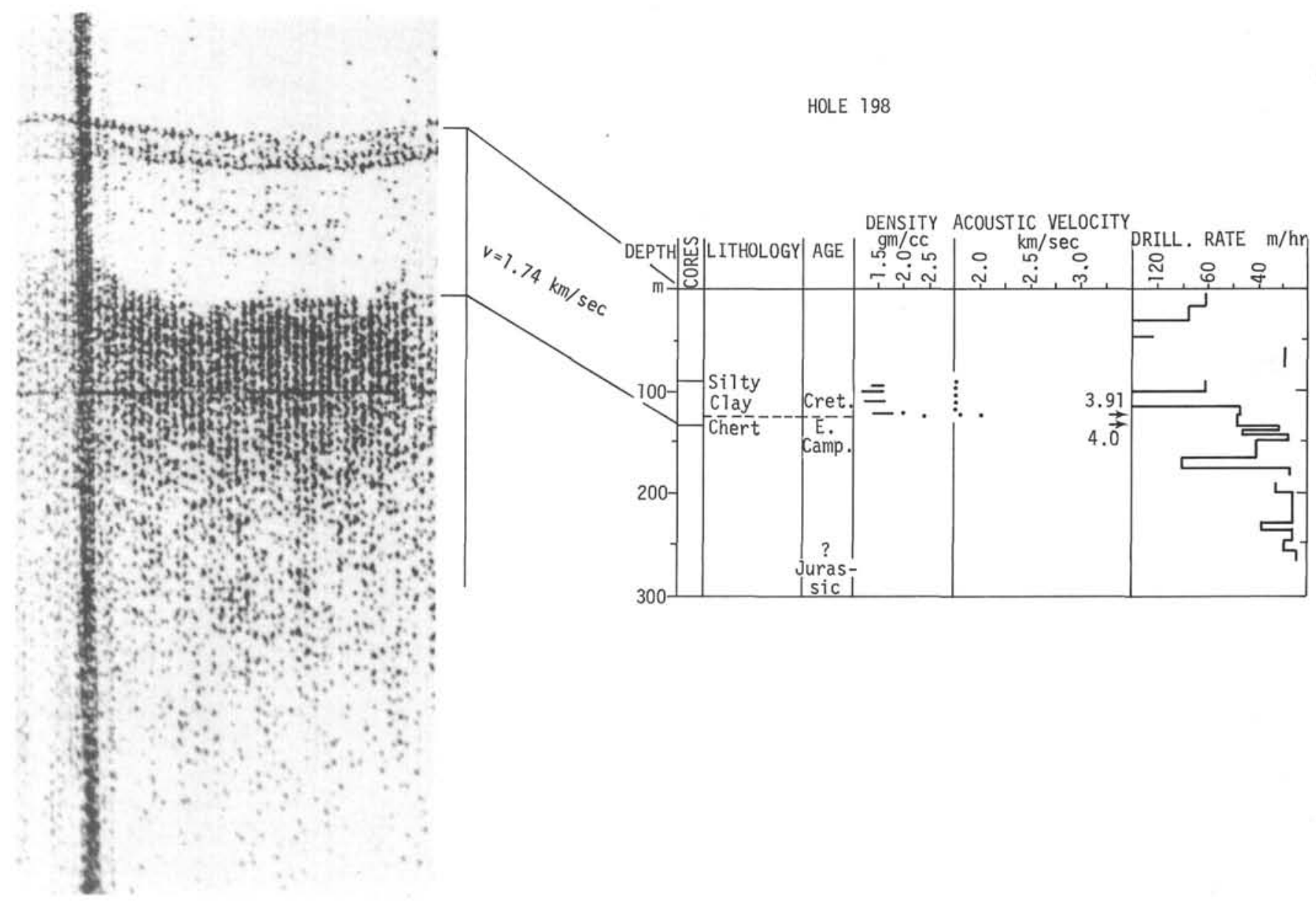

Figure 5. Correlation of drilled record at Site 198 with seismic profile.

\section{Core 5 (125-134.5 Meters)}

The yellowish to grayish brown and brown cherts encountered in this part of the stratigrahic succession are finely laminated (individual laminae are from a fraction of a millimeter to two $\mathrm{mm}$ thick) with individual laminae being not very persistent laterally and frequently wedging out within the specimen. Some specimens are ruptured, the cracks being filled with dark brown chert; others show microfaults with vertical displacements of a few millimeters. The core is probably of early Campanian age.

\section{Miscellaneous Samples}

Material recovered from the bumper subs and bit after the hole was abandoned consists of chips of yellowish gray, olive green, pale orange brown, and brown chert; yellowish gray radiolarian-rich siltstone, and indurated light volcanic ash. The bit sample is possibly of Late Jurassic age.

\section{BIOSTRATIGRAPHIC SUMMARY}

Radiolaria are present in varying amounts in Cores $2 \mathrm{~A}$, $3 \mathrm{~A}, 4 \mathrm{~A}$, and $5 \mathrm{~A}$ (100 to 134.5 meters below the sediment surface) and in the bit sample at a total depth of 6116 meters (258 meters below the sediment surface). They are all poorly preserved except for rare well-preserved Radiolaria in Core 5. Foraminifera are rare and poorly preserved throughout Core 3 and in Sections 1 through 3 of Core 4. Nannofossils are entirely lacking.

\section{Mesozoic Radiolaria}

Radiolaria in Cores 2A, 3A, and Core 4A, Sections 1 through $4,25-27 \mathrm{~cm}$, are too rare and poor to make an age determination of other than Late Cretaceous and this is made on the basis of the probable early Campanian age of the abundant Radiolaria in the remainder of Core $4 \mathrm{~A}$ and the rare Radiolaria in the core catcher of Core $5 \mathrm{~A}$. The bit sample of attempted Core 5A yielded common poorly preserved Radiolaria. The oldest identifiable species, Dictyomitra rotunda, D. leptoconica, and Syringocapsa agolarium, suggest an association with the Sethocapsa trachyostraca assemblage.

\section{Mesozoic Foraminifera}

The same unique assemblage of agglutinated (siliceous) foraminifera was found in Hole 198A (Core 3, Sections 1-6, and Core 4, Sections 1-3) as in Hole 196. This assemblage consists mainly of new species (see biostratigraphic summary of Site 196) and has no similarity with microfaunas described from the Cretaceous deposits of California, the Gulf Coast, the USSR, Japan, some European countries, and other locations. The age of zeolitic brown clays with peculiar representatives of Haplophragmoides, Labrospira, Plectorecurvoides, Praecystammina, Bolivinopsis, Pseudobolivina, Ammodiscus, Glomospira, and Paratrochamminoides can be determined tentatively as Campanian-Santonian. The microfauna is described in a separate chapter of this report. 
Biogenic components found in Site 198 cores are summarized as follows:

\section{Core 1A:}

Foraminifera: none.

Nannofossils: none.

Radiolaria: Very rare, very poor Radiolaria in the corecatcher only.

\section{Core 2A:}

Foraminifera: none.

Nannofossils: none.

Radiolaria: Very rare, very poor Radiolaria in the corecatcher only. Dictyomitra spp. and fragments of saturnalin rings.

\section{Core 3A:}

Foraminifera: Zeolitic and zeolitic-limonitic brown clays of all Sections (1-6) are characterized by very peculiar agglutinated (siliceous) foraminifera with very small thin-walled shells-various species (mainly new ones) of Haplophragmoides, Labrospira, Praecystammina, Plectorecurvoides, Bolivonopsis, Pseudobolivina, Ammodiscus, Glomospira, Hormosina, Paratrochamminoides. Tentative age-Campanian-Santonian.

Nannofossils: none.

Radiolaria: Very rare, poor Radiolaria. Dictyomitra spp. and 1 saturnalin ring.

\section{Core 4A:}

Foraminifera: Zeolitic brown clays in Sections 1-3 contain assemblages of very peculiar agglutinated (siliceous) foraminifera-mainly new species of Haplophragmoides, Labrospira, Plectorecurvoides, Praecystammina, Bolivinopsis, Paratrochamminoides, Ammodiscus, Glomospira, etc. (the same as in Core 3). Tentative age Campanian-Santonian.

Nannofossils: none.

Radiolaria: Sec. 1 through 4, 25-27 cm with very rare, poor Radiolaria, considered as Late Cretaceous on the basis of the early Campanian age of the abundant Radiolaria in the remainder of Core 4. Present are Dictyomitra torquata, Theocampe salillum, and Amphipyndax enesseffi.

\section{Core 5A:}

Foraminifera: none.

Nannofossils: none.

Radiolaria: In the core catcher poor and good, rare Radiolaria. Among them Dictyomitra torquata and Theocampe salillum. Early Campanian.

\section{Core 6A:}

Foraminifera: none.

Nannofossils: none.

Radiolaria: Among the poor Radiolaria in the center bit sample between Cores 5 and 6 , the oldest forms recognized are Dictyomitra rotunda, D. leptoconica, Syringocapsa agolarium, and small forms of the Sphaerostylus lanceola group.

\section{PHYSICAL PROPERTIES}

The results of bulk density and sonic velocity measurements for Site 198 are shown in Figure 6.

Bulk density measurements were made on core sections and individual samples by GRAPE, syringe, and water displacement methods. Although samples for testing were available only from an about 50 -meters-thick interval of the section, this interval included the significant unconsolidated sediment-chert interface. The change is quite rapid in Core 4 at about a 125 -meter subbottom depth. The density of the sediment increases from an average of about 1.5 $\mathrm{gm} / \mathrm{cm}^{3}$ and becomes much more variable due to the increasing presence of consolidated lumps of ash. Thus, individual samples from this level can have much higher densities than the average across the section as determined by the GRAPE instrument. The recovery in the next core barrel consisted only of relatively high density chert.

The density measurements are closely paralleled by the velocity measurements, which show an increase from 1.5 $\mathrm{km} / \mathrm{sec}$ to $4.0 \mathrm{~km} / \mathrm{sec}$ in samples taken from Core 4 $(119-125 \mathrm{~m})$. There is also great variability in the section, with velocities in relatively uniform sections cut from the

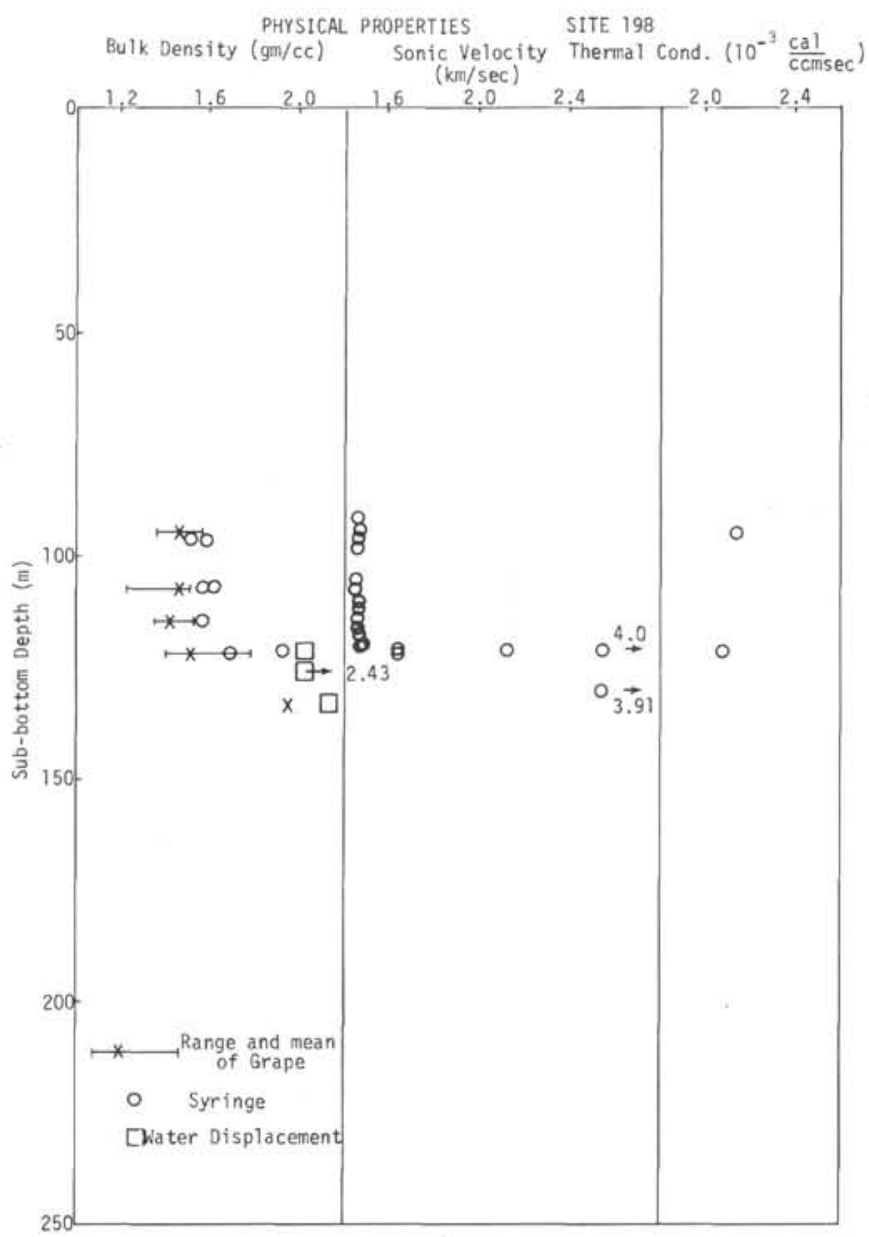

Figure 6. Measured values of bulk density and compressional sonic velocity vs. depth below sea floor at Site 198. 
core of about $1.63 \mathrm{~km} / \mathrm{sec}$ and velocities in lumps of indurated ash as high as 4.0. The one piece of chert from below this level which was large enough for a velocity determination had a velocity of $3.31 \mathrm{~km} / \mathrm{sec}$.

Thermal conductivity measurements were made on one section each of Cores 1 and 4 . These sections were given 12 hours to come to constant room temperature in the unsplit core liner and then measured at five evenly-spaced intervals using the needle probe technique of von Herzen. The figures presented on the following graph are averages for the sections measured; the averages being calculated on the basis of thermal resistivity and then corrected for estimated bottom temperature and pressure. Since Core 4 is in the transition from clay to chert, the figure of $2.15 \times 10^{-3}$ $\mathrm{cal} /{ }^{\circ} \mathrm{C} \mathrm{cm}$ sec from Core 1 at about 95 meters is obviously more representative of the unconsolidated sediments in this area and compares with the figure of 2.27 given by Langseth and von Herzen (1970) for the $5^{\circ}$ by $5^{\circ}$ region in which Site 198 is located. Since thermal conductivity seems to change rather rapidly with location in this area, both figures could easily be correct.

\section{CONCLUSIONS}

The crust in the abyssal basin north of Marcus Island was formed prior to the Late Cretaceous, probably in the Jurassic. The basement was not reached, but the calcareous nature of the basal sediments suggests definitely high sedimentation rates. If the deepest seismic reflections obtained with present equipment are indeed from igneous basement, the age could not be many millions of years older than the oldest samples from this hole. The top of the opaque layer lies in the Upper Cretaceous at approximately early Campanian and, therefore, the assumption of a time stratigraphic nature of the acoustic opaque layer is again refuted. The hole was terminated because of equipment failure. Poor recovery in the chert section was due in part to the driller's fear of sticking while coring in the chert as well as the usual problem of poor recovery with the present bits.

An interval velocity of 1.74 for the transparent layer above the chert is consistent with other results. The origin of the anomalously thick upper transparent layer, which allowed spudding in at this location, is not apparent. It could be the result of contour current deposition of the same late Tertiary sediments as seen in Holes 194, 195, and 196 since wind or surface current transport seems to be excluded because of distance from source.

\section{REFERENCE}

Langseth, M. G. and von Herzen, R. P., 1970. Heat flow through the floor of the world oceans: The Sea, Maxwell, A. E. (Ed.), V. 4, p. 299-353. 


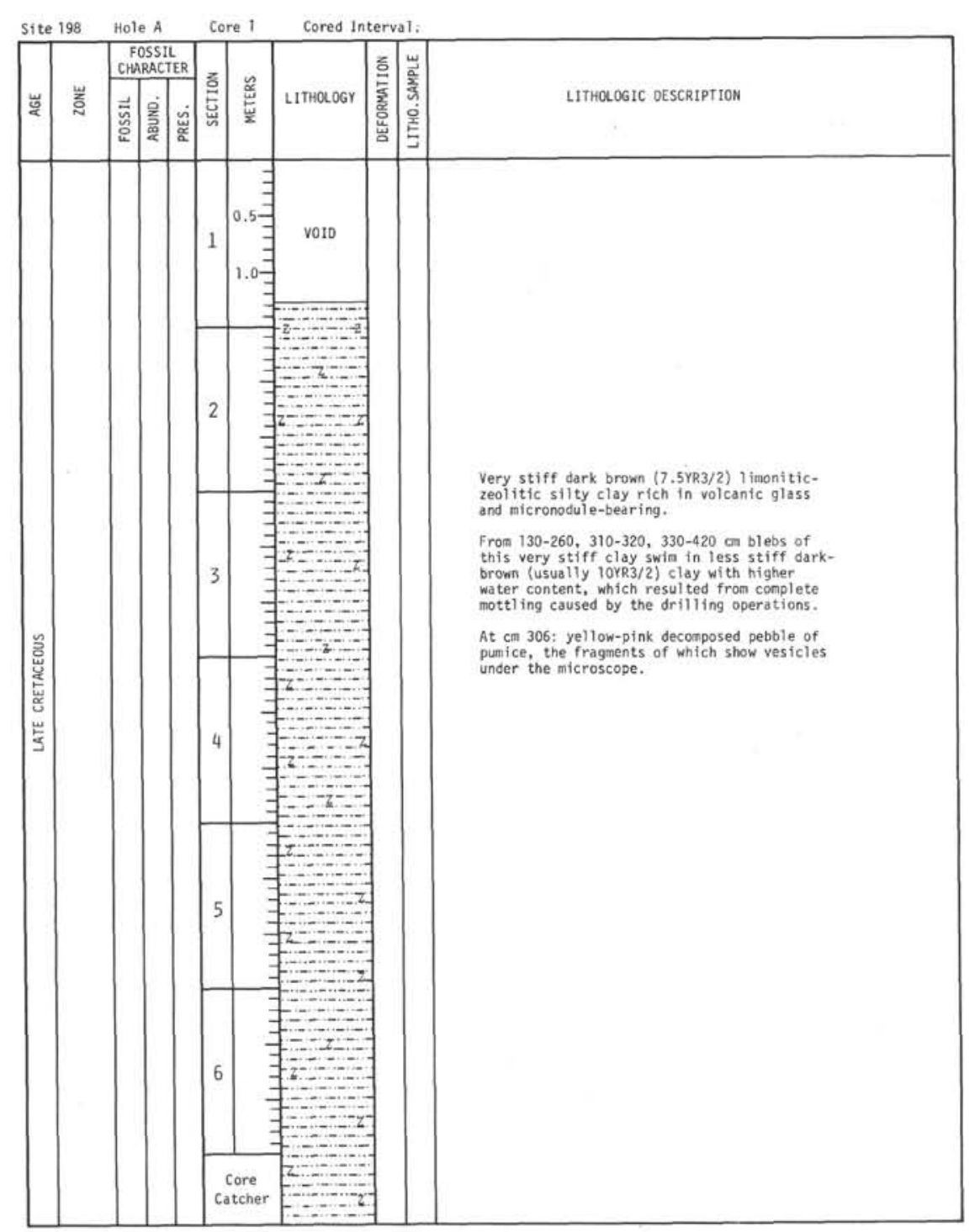

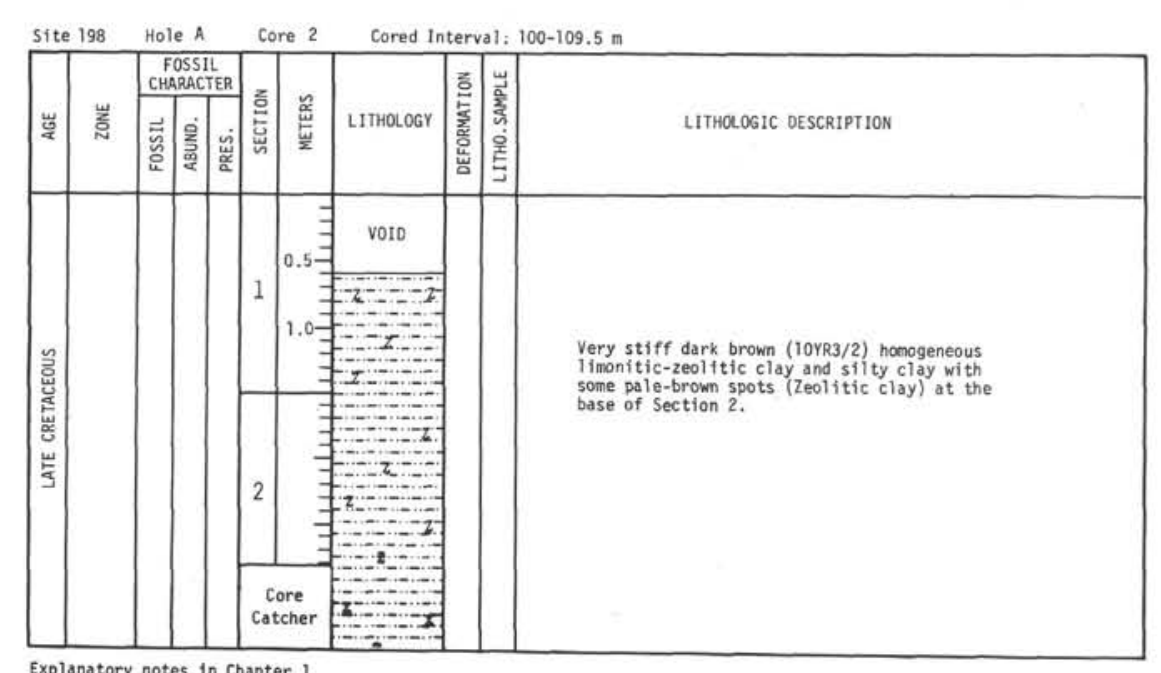

Explanatory notes in Chapter 

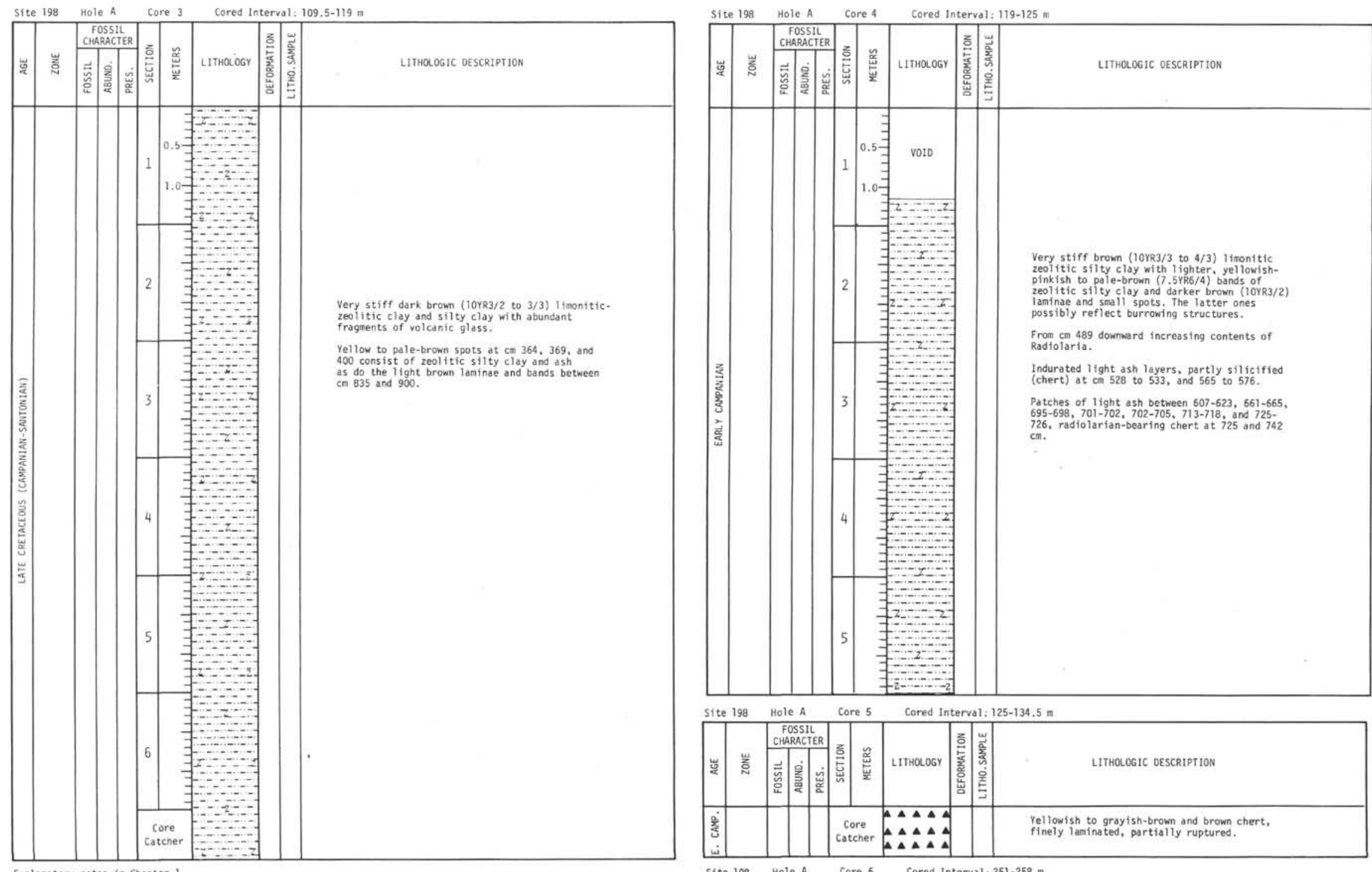

\begin{tabular}{|c|c|c|c|c|c|c|c|c|c|}
\hline \multicolumn{2}{|c|}{ Site 198} & \multicolumn{4}{|c|}{ Hole A Core 6} & \multicolumn{4}{|c|}{ Cored Interval: $251-258 \mathrm{~m}$} \\
\hline \multirow[b]{2}{*}{ 岁 } & \multirow[b]{2}{*}{ 訔 } & $\begin{array}{c}\text { FOS } \\
\text { CHAR }\end{array}$ & ASIL & & & & ż & $\overleftrightarrow{a}$ & \\
\hline & & 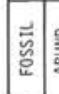 & $\dot{\underline{\underline{z}}}$ & 总 & 岂 & LTTHOLOGY & 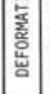 & 资 & LITHOLOGIC OESCRIPTION \\
\hline & & & & & $\begin{array}{l}\text { ore } \\
\text { tcher }\end{array}$ & & & & NO RECOVERY \\
\hline
\end{tabular}




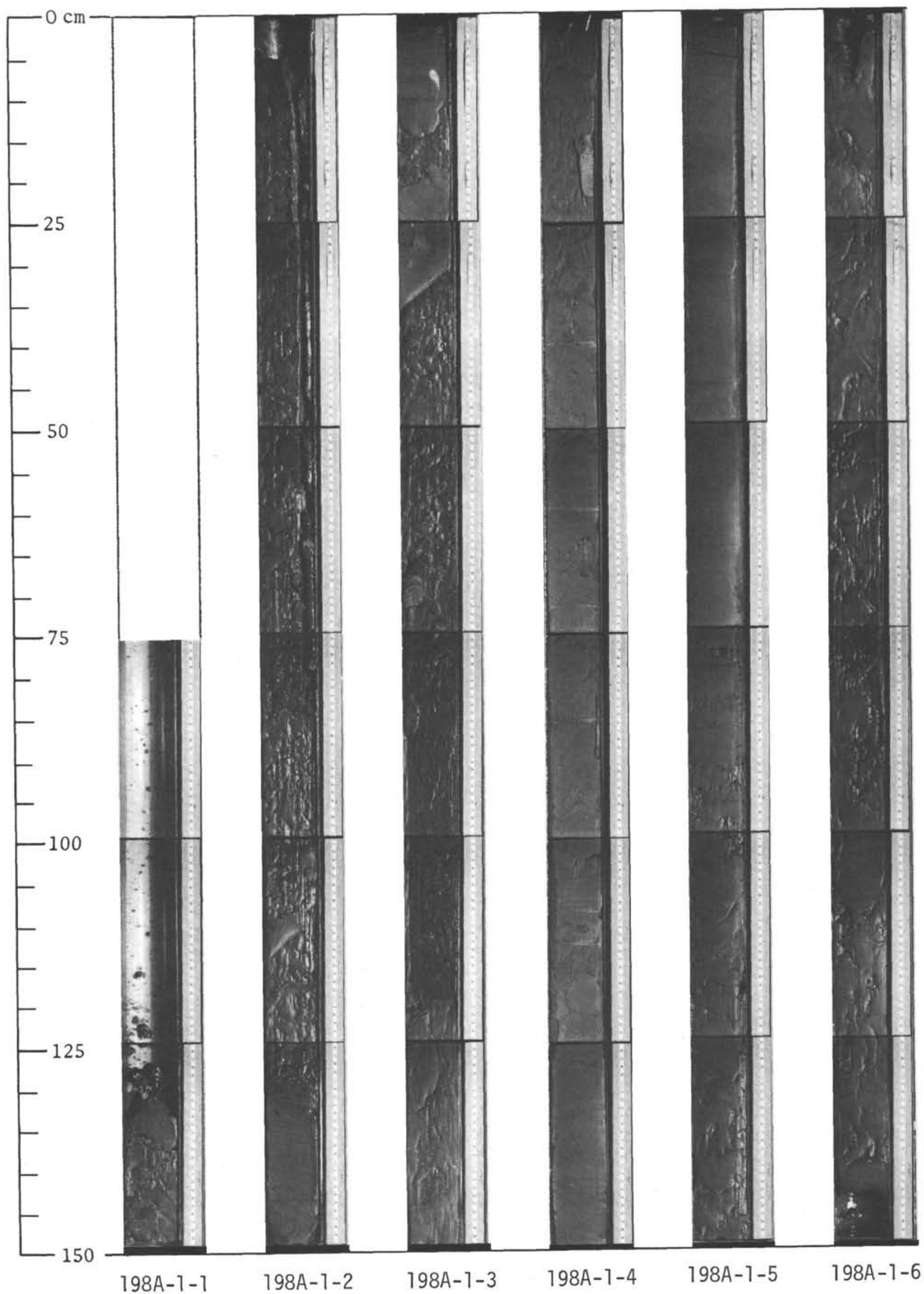




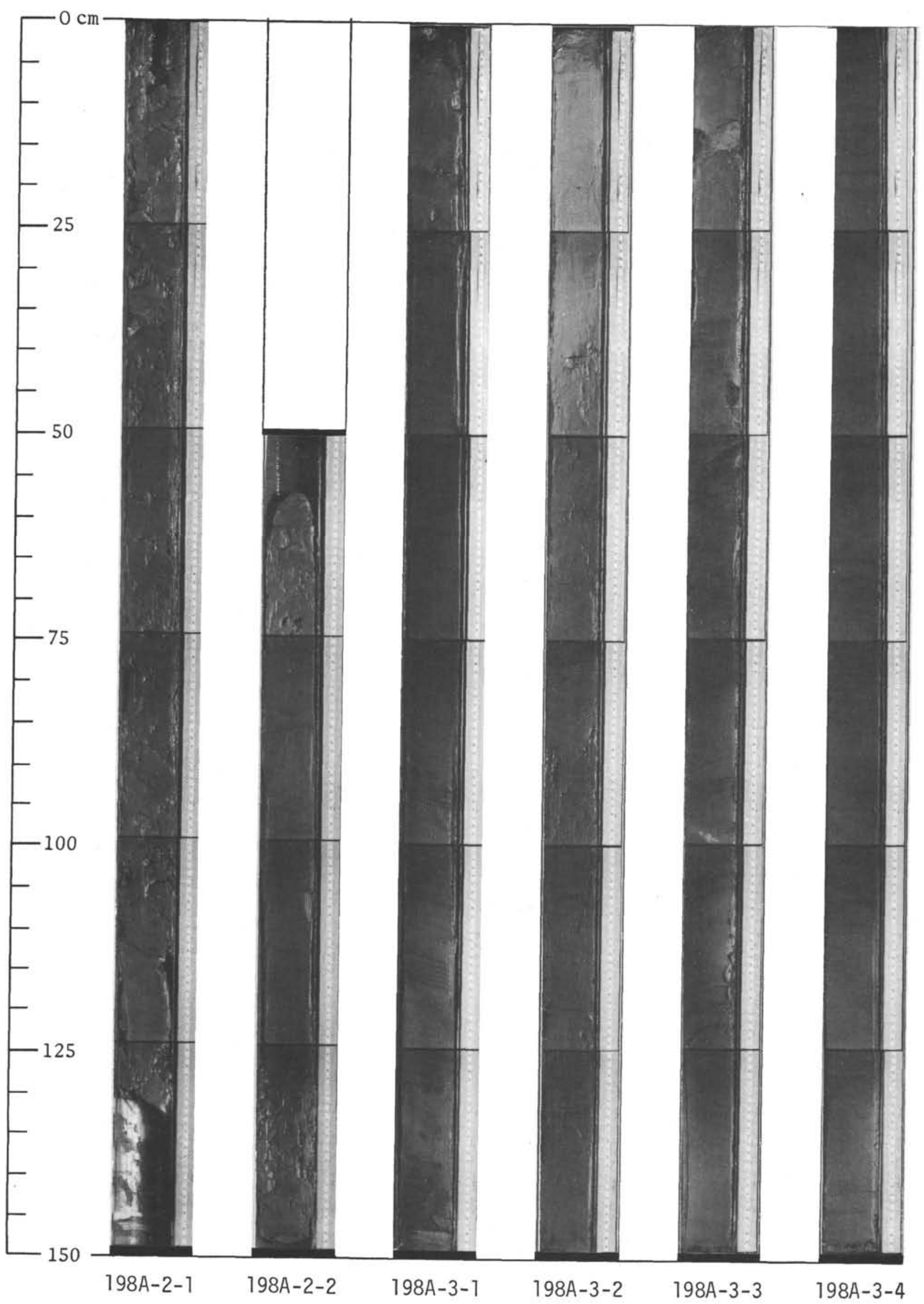




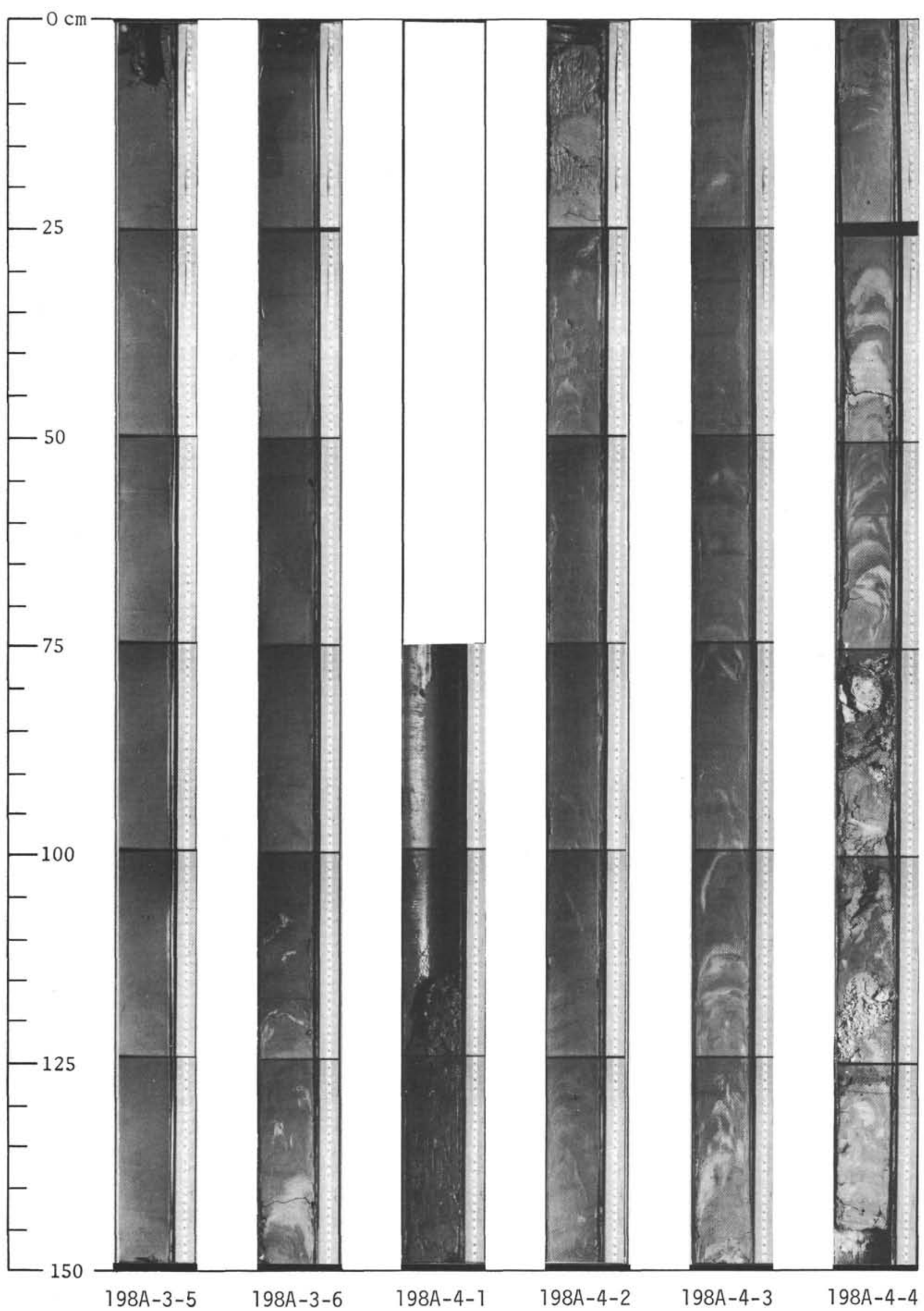




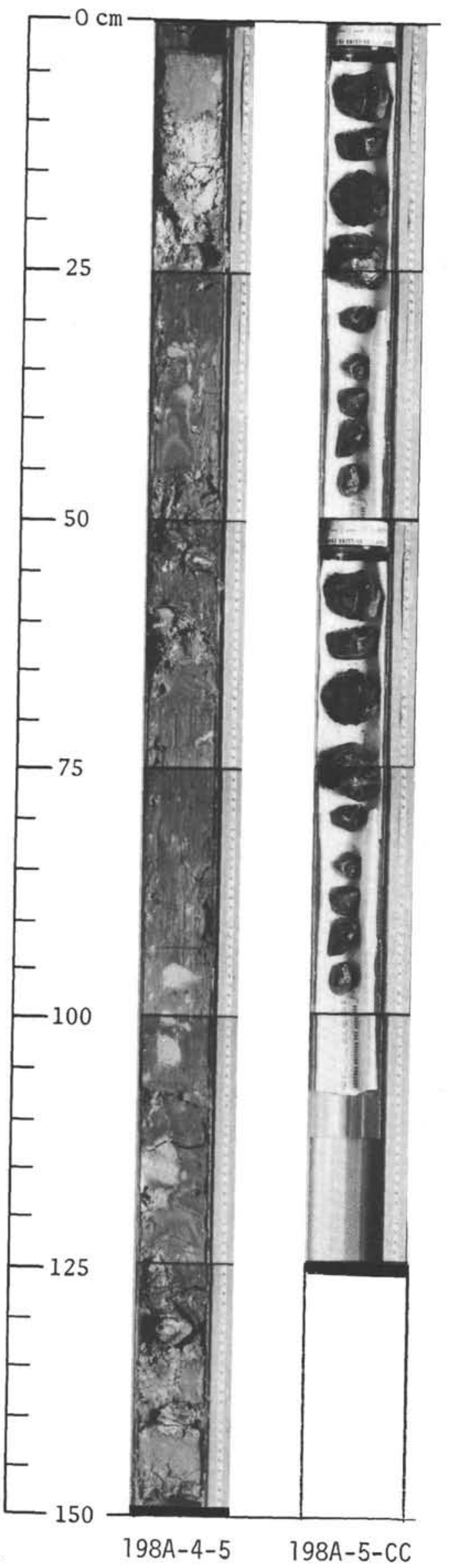

